\title{
“NA SAÚDE E NA DOENÇA”: O MITO DO SALVADOR NA FIGURA DO PRESIDENTE TANCREDO NEVES
}

\author{
Uliana Kuczynski
}

RESUMO: A presente pesquisa intenta mostrar a possível "heroificação" de Tancredo de Almeida Neves. Mesmo eleito indiretamente, esse seria o primeiro civil a assumir a presidência após vinte e um anos de regime ditatorial, não fosse uma doença o ter acometido, levando-o a falecer antes da posse, em 21 de abril de 1985 - dia de Tiradentes, o herói nacional. Esse evento de grande comoção no país leva-nos ao período de reabertura democrática, no qual Tancredo é quem representaria o fim da ditadura militar. Nesse ínterim e com base no trabalho de Raoul Girardet pode-se vislumbrar o processo de construção de um mito - o Mito do Salvador. Isso pela trajetória política de Tancredo Neves, que o identifica como um líder carismático, principalmente por encabeçar a campanha do MDB (Movimento Democrático Brasileiro - em resistência aos militares) e pelo momento de fragilidade da política brasileira na transição para o regime aberto, configurando uma relação de reciprocidade nos anseios do líder com os do povo e vice-versa. Para consolidar esse processo de sacralização, tomamos como base as capas da revista Veja, periódico que estampou, durante todo o período em que o presidente estivera enfermo, a "luta" contra a doença. As imagens publicadas, atreladas ao processo histórico investigado a partir deste evento (doença - falecimento) e deste sujeito (o civil que não tomou posse), formam um discurso que culmina na possibilidade, inclusive, de enxergá-lo como um mártir. Conotações do sagrado incutidos no imaginário político serão discutidos para confeccionar, assim, o Mito do Salvador.

PALAVRAS-CHAVE: redemocratização, Tancredo Neves, mito do salvador.

E o anjo lhes disse: Não temais; porque eis aqui vos trago novas de grande alegria, que o será para todo o povo: é que hoje vos nasceu, pois, na cidade de Davi, o Salvador, que é Cristo, o Senhor (Lucas 2: 10,11).

Certamente a maior referência que o mundo ocidental contemporâneo tem de Salvador está no cristianismo: Jesus Cristo, 
que veio à terra para salvar a humanidade e colocar uma ruptura na ordem vigente. Mais do que as promessas de perdão dos pecados e da redenção da alma, sabemos que esta figura, esse líder carismático, causou e provoca ainda hoje impactos interessantes sobre o imaginário social, político, sobre a cultura e até nos aspectos econômicos na chamada "Era cristã".

No entanto não é no cristianismo que este trabalho irá focar. Tampouco nos impactos que este causou na sociedade contemporânea. Serão discutidos apenas alguns levantamentos em torno da questão do Salvador. Do mito do Salvador. A ligação com a figura de Jesus Cristo é em relação aos atributos sagrados que são conferidos ao político, ao fato do mito político compreender um sistema de significados que acaba por levar os sentimentos coletivos a esse terreno do sagrado.

Para perceber tais (re)significações usaremos um personagem, um sujeito, uma figura carismática da República brasileira na hipótese de sua sacralização, buscando descrever um processo de "heroificação" de Tancredo de Almeida Neves (1910 - 1985) - o primeiro civil que assumiria a presidência da República após vinte e um anos do regime ditatorial militar, não fosse uma doença o ter acometido, impedindo-o de tomar posse, e levando-o ao falecimento.

Esse evento é instigante pela comoção nacional causada por motivo de sua morte. O líder que personificaria o fim da ditadura militar e a retomada da democracia (mesmo que eleito indiretamente), não chega ao posto de presidente do Brasil. A população recebeu isso com temor a outro golpe, ou ressabiados com a posse do vice José Sarney (que era dissidente do Partido Democrático Social - PDS, o partido pró-governo militar durante a ditadura, ex-ARENA), chagando até o ser enredada a idéia de assassinato perpassando a opinião pública. ${ }^{1}$ Não só sua campanha eleitoral, cujo slogan era "Muda Brasil", elevou sua imagem e atraiu adeptos, como a notícia

${ }^{1}$ SKIDMORE, Thomas. Brasil: de Castelo à Tancredo. Rio de Janeiro: Paz e Terra, 1988. 
da enfermidade, culminando com sua morte causou grande abalo entre os brasileiros. O trabalho exaustivo da mídia em cima do curto período que será aqui recortado (da notícia da doença, em 24 de março de 1985 até o falecimento, a 21 de abril), terá um papel essencial na promoção do herói, conforme veremos.

Em meio ao desgaste da estrutura representativa da República (herança da época de repressão) esse exemplo chama atenção, então, para pensarmos como a sociedade recebe esse tipo de situação, que mexe com os sentimentos coletivos através do quadro político.

Mas antes de entrarmos no contexto do problema levantado, cabem algumas ressalvas acerca de como transitar nesse "terreno lodoso" que é o do imaginário e das paixões humanas; alguns breves esclarecimentos acerca de como e porquê o historiador se aventura em tal terreno.

$$
* * *
$$

O tipo de abordagem que utilizaremos - a qual envolve política com sentimentos, representações, subjetividade - afasta-se do viés mais estrutural, mais "sociográfico", no qual a História se ancorava antes de passar por um rearranjo na sua metodologia e até no seu objeto. Tal reestruturação do fazer histórico vem dos debates da Escola de Annales na década de oitenta, que José Carlos Reis chamou de um tournant critique (transição de um momento a outro, uma "reviravolta"). O que se reergue a partir destes debates é o olhar sobre o sujeito, a narração, as nações e a história política, a biografia, o evento, tudo reivindicando entender a sociedade como "uma multiplicidade de consciências em interação". 2

\footnotetext{
${ }^{2}$ REIS, José Carlos. Escola dos Annales - A inovação em História. São Paulo: Paz e Terra, 2000, p. 129. Estas modificações visam, sobretudo, fugir do rigor que as ciências sociais acabaram por emprestar ao método historiográfico. Esse rigor teria atribuído à visão de sociedade como uma “coisa", segundo algumas das críticas. Ver também: CHARTIER, Roger. O Mundo como representação. Texto publicado
} 
Os sentimentos expressados na coletividade devido a um determinado quadro político fazem parte do imaginário social. Conceito derivado da palavra imaginação, ele não é um pensamento organizado, mas é reconhecível em uma sociedade por ser um sistema de representações pelo qual esta apreende a sua realidade e firma sua identidade, reconhecendo-se e mantendo-se enquanto tal. ${ }^{3}$ As funções, os papéis, as necessidades, têm um conjunto de significados que se evidenciam na experiência vivida. ${ }^{4} \mathrm{O}$ exercício de apreendêlos, então, torna-se o desafio do historiador.

Já com relação às paixões, Pierre Ansart (naquele tournant critique dos anos oitenta) mostra que, ao contrário das apostas feitas no fim das ideologias pelo advento do Estado técnico e racionalizado, elas ainda movem a política. Ora, o sujeito histórico - o ser humano continua a desempenhar papéis, reagir, crer, questionar, fazer parte daquela "multiplicidade de consciências" 5 acima descritas como a própria História, a partir de suas paixões. Porém Ansart alerta para que a análise não seja fixada em uma oposição razão/emoção, uma vez que as emoções são acionadas, são gestadas, e por vezes gerenciadas e controladas pela razão. ${ }^{6}$

Para explicar o mito, o mesmo autor diz que ele surge como uma narrativa que explica a realidade. Às vezes é interpretado como

com permissão da revista Annales nov/dez 1989, n. 6, p. 1505-1520 em Estudos Avançados, 1991, n. 5, p. 173-191.

${ }^{3}$ ANSART, Pierre. Ideologias, Conflitos e Poder. Rio de Janeiro: Zahar, 1983. p. 22.

4 Sobre esse assunto, ver também PATLAGEAN, Evelyne. A História do Imaginário. In: LE GOFF, Jacques (Org.). A História Nova. São Paulo: Martins Fontes, 1990, p. 292-316, onde a autora designa que: “o domínio do imaginário é constituído pelo conjunto das representações que ultrapassam o limite dos fatos comprováveis pela experimentação e pelos encadeamentos dedutivos”, p. 292.

${ }^{5}$ REIS. Op. cit.

${ }^{6}$ BREPOHL, Marion. Leituras da História: La gestion dês passions politiques Pierre Ansart. Texto apresentado no III Evento de Extensão em Pesquisa Histórica Fontes Históricas: Métodos e Tipologias, 2008. 
uma camuflagem, uma idéia de ilusão ${ }^{7}$, mas "O mito não é exatamente uma crença, um ato de fé, é a experiência cotidiana no imaginário vivido, o modo de relação dos homens consigo mesmos, com o mundo e com o outro". ${ }^{8}$ Portanto o mito legitima e designa poderes, submissões, deveres, obediência. Atesta e regulamenta. E por conta disso pode ser identificado não somente nas sociedades primitivas - comum em muitos estudos - mas revela-se um objeto muito observável na contemporaneidade.

O historiador Raoul Girardet alerta que: "O mito só pode ser compreendido se é intimamente vivido, mas vivê-lo impede dar-se conta dele objetivamente. Objeto de estudo, ele tende, inversamente, a imobilizar-se em uma sucessão de dados estáticos; tende igualmente a se esvaziar de seu conteúdo emocional, ou seja, do essencial de si mesmo". ${ }^{9}$ o que torna mais instigante o trabalho, requerendo uma devida cautela para focalizar a questão como um fenômeno social. Pois o mito é construído a partir da realidade histórica, em que tempo e espaço (portanto a sociedade) são suas ferramentas. ${ }^{10}$

Vale a sugestão de Roger Chartier, que busca trabalhar:

(...) penetrando nas meadas das relações e das tensões que as constituem a partir de um ponto de entrada particular (um acontecimento, importante ou obscuro, um relato de vida, uma rede de práticas específicas) e considerando não haver prática ou estrutura que não seja produzida pelas representações, contraditórias e em confronto, pelas quais os indivíduos e os grupos dão sentido ao mundo que é o deles. ${ }^{11}$

A despeito do que foi exposto acima, como vislumbrar, então, um único sujeito, uma figura política em meio a esse "sistema de representações”? Seria Tancredo Neves um líder carismático equiparado a um mito - um mito do Salvador? Ele enquanto pessoa,

\footnotetext{
${ }^{7}$ GIRARDET, Raoul. Mitos e mitologias políticas. São Paulo: CIA das Letras, 1987.

${ }^{8}$ ANSART. Op cit, p. 23.

${ }^{9}$ GIRARDET. Op cit, p. 23.

${ }^{10}$ Idem.

${ }^{11}$ CHARTIER. Op cit, p.177.
} 
enquanto homem público (um estadista), como autêntico defensor da democracia? Ou talvez fora o próprio processo histórico que permitiu questioná-lo como um Salvador? Além dessas questões, procuremos pensar naquilo que fabrica e transmite a representatividade do evento para os sentimentos coletivos nacionais: qual a possibilidade da sacralização deste Homem através do trabalho da mídia.

$$
* * *
$$

Nascido em São João Del Rei, Minas Gerais, em março de 1910, Tancredo de Almeida Neves, advogado, iniciou a carreira política na década de trinta, nas campanhas da Aliança Liberal. Atuou em cargos do legislativo municipal, estadual e, em 1950 fora deputado federal no governo presidencial de Getúlio Vargas, quando Juscelino Kubistchek elegeu-se governador de Minas Gerais. A partir de então sua vida pública começa a ter ressonância fora daquele Estado, dialogando com outras instâncias do poder e da federação. ${ }^{12}$

Tancredo exercera cargos de importância no governo federal de Juscelino, como o de Ministro da Justiça, em 1953. Sempre participava das principais decisões do governo e seus conselhos eram acatados. Candidatou-se ao governo de seu Estado natal, mas não obteve êxito. No regime parlamentarista é nomeado $1 .^{\circ}$ Ministro de João Goulart, conseguindo reduzir as rivalidades entre as principais correntes políticas do país: "o gabinete de Tancredo (...) se caracterizava por uma política de compromisso para obter um amplo consenso nacional”. ${ }^{13}$ Quando o Movimento Democrático Brasileiro (MDB) funde-se com o Partido Progressista - PP (formando o novo Partido do Movimento Democrático Brasileiro - PMDB) Tancredo Neves é eleito vice-presidente do partido, e, antes das eleições que interessam neste trabalho, elege-se governador de MG em 1982.

\footnotetext{
${ }^{12}$ As informações sobre a biografia política estão contidas no Dicionário Histórico Biográfico Brasileiro, p. 2382-2388.

${ }^{13}$ Idem, p. 2386.
} 
Ora, esse caráter moderado (centro-esquerdista), somado à larga experiência como homem público permitiu sua escolha para representar a oposição ao governo militar nas eleições de 1984, de acordo com o que veremos. O historiador Thomas Skidmore, inclusive, caracteriza-o como o "candidato da conciliação", e também menciona que pelo seu discurso nada extremado e pela idade já avançada (74 anos) Tancredo era visto como um "pai”. ${ }^{14}$

Nesse sentido, temos a figura carismática de Tancredo Neves, sempre em meio aos líderes populistas, atuando com representatividade e com seu caráter conciliador. Raoul Girardet diz que o Salvador aparece como um lutador, um combatente, sempre correndo riscos, muitas vezes associado ao "farol", à "coluna", ao "iluminado". Mas é principalmente com a figura do pai protetor, no sentido de uma relação de filiação (como tutor), que podemos identificar Tancredo. Uma figura que estampa uma relação de fidelidade (como guia). ${ }^{15}$

O Salvador é ainda aquele que restaura a segurança e a ordem que estava ameaçada ou subverte-a, fundando outra ordem institucional. ${ }^{16}$ Mas que ordem era essa? Ameaçada, correndo perigo? Talvez nem tão exageradamente, mas o momento era delicado e de grandes expectativas em relação à redemocratização.

No caso do Brasil em 1985, era esse o palco: uma sociedade abalada por anos de autoritarismo, mas que já experimentava aquele processo lento, gradual e cuidadosamente tutelado pelos militares de abertura democrática. ${ }^{17}$ À propósito, “(...) o avanço democrático ocorreu no interior do sistema autoritário, forçando-o a reformar-se

\footnotetext{
${ }^{14}$ SKIDMORE. Op cit.

${ }^{15}$ GIRERDET. Op cit.

${ }^{16}$ Idem.

17 Vale ressaltar que estamos buscando distância das interpretações dicotômicas entre razão/emoção, conforme já foi dito. Então, percebamos que a receptividade do herói pela sociedade não significa uma anomia social, tampouco uma situação que mostrava "irracionalidade". As manifestações tanto racionais como dos sentimentos estão imbricadas umas nas outras.
} 
além da política de distensão". ${ }^{18}$ Ou seja, o próprio desgaste do aparelho político-militar na sua crescente debilidade dava, de certa forma, espaço tanto à oposição quanto às aspirações populares em relação à democracia. O Brasil estava no período de gestação da chamada "Nova República" ${ }^{19}$ - com todos os cuidados e riscos de concebê-la.

Ora, já no início da década de oitenta, o então presidente João Baptista Figueiredo (1979 - 1985) enfrenta situações mais delicadas em relação à abertura. $\mathrm{O}$ país se encontrava em uma de suas piores crises econômicas ${ }^{20}$ e a campanha pelas "Diretas Já!" deu muitas desvantagens ao PDS (partido que apoiava os militares). O partido pró-governo perdera a maioria na Câmara dos Deputados e nos governos estaduais, e, por outro lado, o PMDB (oposição) se fortalecia.

Apesar da Emenda Dante de Oliveira, que instituiria eleições diretas para a presidência, não ter sido aprovada $^{21}$, o que ficou evidente foram as manifestações da população almejando participação política. Eram pessoas ligadas aos partidos, líderes sindicais, personalidades e artistas que atribuíam um caráter de "show

${ }^{18}$ OLIVEIRA, Eliézer Rizzo de. De Geisel a Collor: Forças armadas, transição e democracia. Campinas: Papirus, 1994, p. 110. Note-se que aqui o objetivo não é discutir se os atentados contra os direitos do cidadão acabaram por manchar a farda da própria autoridade militar. Tampouco avaliar os resultados dos movimentos de resistência. Consideremos essa multiplicidade e complexidade do processo, mas, como não há espaço, vejamos um panorama mais geral e do viés institucional da República.

19 A expressão "Nova República” foi cunhada por Tancredo Neves, então governador de Minas Gerais, ao se lançar candidato à Presidência da República, com o significado de compromisso com a superação definitiva do regime militar, por meio do pleno restabelecimento do regime democrático.

${ }^{20}$ BRESSER-PEREIRA, Luis Carlos. Economia Brasileira. São Paulo: Ed. 34, 1998, cap 27.

${ }^{21}$ Dos 479 deputados, 298 votaram à favor (55 desses votos eram pedessistas), 65 contra e 3 se abstiveram. Entretanto, por causa dos 112 parlamentares que não compareceram, faltaram 22 votos para a aprovação da lei. 
business" à essa questão. ${ }^{22} \mathrm{~A}$ imprensa, por sua vez, ficava com o fundamental papel de divulgar essa efervescência, popularizando-a. São destaque a participação do PT e do líder Ulysses Guimarães, que esteve ao lado de Tancredo. ${ }^{23}$ Percebe-se, então, que a identificação do povo com os ideais defendidos pela oposição toma proporções significativas.

As eleições presidenciais ocorreriam, então, indiretamente. ${ }^{24}$ A convenção do partido da situação nomeou Paulo Maluf para a campanha eleitoral. ${ }^{25}$ Ele fora prefeito e governador em São Paulo, era conservador, tinha uma boa publicidade e conquistara alguns políticos por ser "organizado e ter uma boa liderança" ${ }^{26}$ Contudo a nomeação de Maluf fora motivo de discórdia para outros pedessistas, resultando na dissidência do PDS e enfraquecendo o partido inclusive, muitos políticos civis que apoiavam os militares se desvencilharam dele.

Em oposição, a convenção do PMDB (cada vez mais unificado) escolhe Tancredo de Almeida Neves para candidato a presidência. O estadista de caráter moderado e conciliador consegue apoio inclusive de alguns militares ${ }^{27}$ e daqueles dissidentes de Paulo Maluf, que formaram o Partido da Frente Liberal (PFL), encerrandose assim, a Aliança Democrática.

É válido lembrar que o vice, José Sarney, entra como um considerável atrativo para os votantes do PFL. Pois como um exmilitante da UDN e do PDS, “dissidente respeitado e sem atritos”,28,

${ }^{22}$ SKIDMORE. Op cit. As maiores concentrações se davam em São Paulo e no Rio de Janeiro.

${ }^{23}$ Idem.

${ }^{24}$ Se pensarmos em termos de votação universal, somente em 1989 que essa "saga” da reabertura findará. Com a eleição (direta) de Fernando Collor de Mello.

${ }^{25}$ Disputou a nomeação com Aureliano Chaves, que participara da UDN e da ARENA e fora vice de Figueiredo, e Mário Andreazza, que era militar e atuou em cargos ministeriais de Costa e Silva, Médici e Figueiredo.

${ }^{26}$ SKIDMORE. Op cit.

${ }^{27}$ Idem.

${ }^{28}$ Ibidem, p. 484. 
ele fecharia o quadro para essa 'jogada política' de tendência centralizadora. Jogada essa que garantiu 180 votos ao candidato pedessista Paulo Maluf contra os 480 vitoriosos votos da Aliança Democrática $^{29}$, da "Nova República”, do "candidato da conciliação" Tancredo Neves.

De acordo com o que foi traçado até o momento, temos algumas características do contexto brasileiro que vão de acordo com aquelas oferecidas por Girardet para entender a fabricação do mito do Salvador. Pois para ele, a figura do herói aparece como uma linha de ruptura, respaldada pela própria sociedade que evidencia sua carência por ela. São as aspirações coletivas, conscientes ou inconscientes, que as personagens midiáticas corporificam e por isso tornam-se mitos, figuras aglutinadoras do imaginário de determinada época. A identificação necessária entre a personagem midiática e o público se dá justamente na "humanidade" daquela. A multidão se encontra no chefe, e vice-versa. De um lado o povo reconhece no líder uma representação de seus anseios e, de outro, o líder fala e age enquanto a multidão. É a encarnação (no sentido mais religioso) do povo. ${ }^{30}$

$\mathrm{O}$ historiador francês analisa ainda outros exemplos agrupando-os em quatro "modelos" desse herói sagrado - que não são auto-excludentes. O primeiro seria o exemplo de Moisés: o profeta. "Esse herói lê na História aquilo que os outros não vêem. Ele próprio conduzido por uma espécie de impulso sagrado, guia seu povo pelos caminhos do futuro". Um dos representantes seria Bonaparte, e ainda colocaria Getúlio Vargas e o próprio Tancredo Neves aqui, uma vez que, sendo ele do MDB (Movimento Democrático Brasileiro) e "sabendo do que o povo precisava" movimentou seus planos para redemocratização. Também creio que seja possível inseri-lo no modelo daquele que estabelece uma nova ordem, conforme Girardet. Uma figura imponente que se assegura pela tradição. Ele aponta também a figura de Bonaparte designando um terceiro modelo que

${ }^{29} 17$ abstenções e 9 ausências. In: SKIDMORE. Op cit.

${ }^{30}$ GIRARDET. Op cit. 
seria o herói da ação imediata e ainda um último modelo: o que está na memória coletiva, que volta a atuar no cargo por esse motivo e pelas provações que passou. ${ }^{31}$

Assim, não esqueçamos da indispensável importância que o próprio processo histórico confere à fabricação do herói. Isso porque o herói sagrado está inserido nele, fazendo parte de tal processo. Dessa maneira o herói mira-se na História e na tradição para projetarse no futuro, premeditada ou espontaneamente. ${ }^{32} \mathrm{O}$ herói, lembremos, está sendo entendido nas suas intenções, nas suas iniciativas, como um sujeito que possui uma identidade qualitativa, relativa, variante no tempo, que chamou a atenção de alguma maneira tal qual a impulsionar uma reflexão histórica. ${ }^{33}$

Isso nos permite afirmar o seguinte: a República brasileira, em um período de transição, vai encontrar nesse "pai protetor" a sua "luz". Consciente ou inconscientemente o povo se encontra no líder: seja pelo próprio contexto lento, mas carente da redemocratização, seja pelas convicções políticas do estadista da oposição ou até pelo carisma experiente e conciliador do personagem. Tancredo Neves sabe o que os brasileiros precisam e torna-se a representação desses anseios em um momento delicado. Da mesma forma, o presidente eleito sente-se incumbido de falar e agir no lugar da nação que demonstra conferir à ele a função de implantar seus planos para a reabertura. O líder se encontra no povo e vice-versa.

\section{$* * *$}

Após a eleição, mesmo que indireta, o clima de reabertura parece se aquecer, animando as expectativas para o dia da posse. Contudo, nesse ínterim, ocorre um evento suficientemente intrigante a ponto de se tornar o cerne deste trabalho: o internamento de Tancredo de Almeida Neves na véspera da posse (14 de março), culminando

${ }^{31}$ Idem.

${ }^{32}$ Ibidem.

${ }^{33}$ REIS. Op cit. 
com o seu falecimento depois de mais de um mês internado, em 21 de abril de 1985.

O presidente eleito foi internado em 14 de março de 1985, contra sua vontade - pois receber a faixa seria um ritual indispensável. Pairava ainda uma desconfiança de que os linhas-duras do governo Figueiredo aproveitassem a situação para não transferir o cargo. Além disso, o fato do vice José Sarney representar a transição trazia preocupações dentro do Ministério, pois há poucos meses ele atuava como presidente do PDS, e a desconfiança de que o público não o encararia com as mesmas expectativas era incômoda. ${ }^{34}$

A expectativa da posse frustrada e o quadro de saúde agravado são o estopim para a turbulência desse evento de proporção nacional (e até continental). E para o historiador "o evento testemunha menos pelo que aparece do que pelo que revela, menos o que ele é do que ele deflagra, 'É só um eco, um espelho da sociedade, um buraco' (...)”. ${ }^{35}$ Não devemos nos ater ao fato em si, mas àquilo que ele representa. $\mathrm{O}$ evento pode ser encarado também como algo que inaugurou uma estrutura, inserindo-se nela, uma descontinuidade, uma janela, uma curva, algo de singular no tempo. Nesse caso o evento está refletindo a realidade histórica na qual viveu, agiu, teve influência e consciência um determinado sujeito de vida pública.

Agora resta entrar em um dos mais importantes fatores desta análise: a função da mídia nesse episódio merece ser sublinhada. Se conseguimos vislumbrar uma postura de destaque à figura de Tancredo pelo carisma e atuação política (um líder carismático promovido a herói) e o momento de (re)democratização como palco propício para o processo de heroificação (processo histórico), o papel da imprensa, o chamado "quarto poder" é fundamental para confecção do mito do Salvador.

A Revista "Veja", periódico de natureza política de maior circulação nacional, contemplou todos os sete exemplares que cobrem

\footnotetext{
${ }^{34}$ SKIDMORE, Op cit.

${ }^{35}$ José Carlos Reis descrevendo a visão sobre o tempo presente em Pierre Nora. In: REIS, Op cit, p. 145.
} 
o período do internamento do presidente com o caso estampado na capa, com apelo maior ao ícone, à imagem dele, em detrimento do texto. $^{36}$ Os significados das imagens oferecem um grau de subjetividade instigante, que podem ser transcritos para a realidade do contexto, conforme seguem algumas descrições.

A primeira edição a tratar o assunto traz o fundo amarelo com a manchete "Noite de medo em Brasília: o choque e a posse" em verde: chamamento de interesse nacional. ${ }^{37}$ A edição especial com 25 páginas sobre "as doze horas que abalaram o Brasil" mostra uma fotografia do presidente eleito com expressão de preocupação, cabisbaixo, ao lado de outra imagem um pouco mais larga do vice acenando no dia da posse. Já a partir da edição subseqüente ${ }^{38}$, nota-se uma significativa inversão nas cores (do amarelo-quente para os tons frios de preto e branco) e no pano-de-fundo das capas, que passam a ser fotos do rosto de Tancredo Neves, ocupando a totalidade do espaço. Um rosto preocupado, expressando sofrimento e até agonia, mas que continua ali, presente (pelo menos na imprensa).

As edições de número 864, 865, 867 e 868 intitulam todas as manchetes pelo nome do presidente: “Tancredo: ...", seguido do assunto da semana. Somente o primeiro nome do presidente, e aparecendo repetidas vezes, conota um processo já familiarizado. Tanto pelo personagem-título quanto pela situação. Uma novela cujo enredo tem por "bandido" o quadro comprometedor de saúde do "mocinho"-protagonista. Protagonista da "novela", da revista, da República.

A idade de Tancredo Neves já era avançada e - convenhamos - não é incomum a manifestação de enfermidades. Se tomarmos a segunda e a sexta capa das revistas selecionadas para o recorte

\footnotetext{
${ }^{36}$ Os exemplares estão disponíveis on-line pelo site: http://www.veja.abril.com (ver referências bibliográficas).

${ }^{37}$ VEJA. Noite em Brasília: o choque e a posse. São Paulo: Editora Abril, 20 de março, 1985, n. 863.

${ }^{38}$ VEJA. Tancredo: A luta pela vida. São Paulo: Editora Abril, 27 de março, 1985, n. 864.
} 
estudado, notamos uma sutil crítica, por parte da revista, à própria medicina. ${ }^{39} \mathrm{O}$ exemplar que data do dia 27 de março (a segunda) tem no fundo uma espécie de lençol hospitalar com o devido recorte para cirurgia. Dentro do recorte está a foto de Tancredo, cercada pelos instrumentos cirúrgicos (tesouras e bisturis), parecendo uma ameaça. Já na outra capa (a do dia 24 de abril, três dias após a morte) é explícito o apelo do texto: “Tancredo: por que os médicos mentiram”. Localizado acima da manchete e abaixo da fotografia já familiar, um recorte do boletim médico com o carimbo acusando: "falso". ${ }^{40}$

Sem entrar na questão médica em si - porque não interessa polemizar a respeito, somente perceber o impacto do evento - podese perceber como é construído um discurso que, mais do que culpar os médicos, parece tirar a condição humana do presidente de falecer. Pois ele é um herói, aquele que salvaria a nação, não poderia adoecer, muito menos falecer.

Quanto ao vice José Sarney, ele aparece depois somente num canto de página da edição do dia 10 de abril. ${ }^{41}$ No lado superior esquerdo, em vermelho, está ele sobre uma faixa afirmando: “o governo sem Tancredo”. Aí parecia que a esperança já não era tanta. O povo/público consumidor já estava sendo preparado. Inclusive a cor da inscrição "Veja" não está em vermelho, como no habitual. Nesta tiragem como na próxima ela aparece na "congelante” e serena cor branca.

Sempre a mesma foto exibida (porque sempre em close e cabisbaixo) Tancredo torna-se um ícone. Nas discussões de Chartier sobre a relação de imagem/representação, podemos entendê-la da seguinte maneira: como uma relação homóloga entre uma imagem presente e um objeto (ou pessoa) ausente, ou, uma imagem presente e uma idéia, algo de moral que atribui significado àquele signo

\footnotetext{
${ }^{39}$ Idem.

${ }^{40}$ VEJA. Tancredo: por que os médicos mentiram. São Paulo: Editora Abril, 24 de abril, 1985, n. 868.

${ }^{41}$ VEJA. Dias de dor: a resistência da infecção; o perigo nos pulmões; o choque das operações sucessivas, São Paulo: Editora Abril, 10 de abril, 1985, n. 866.
} 
imagético. ${ }^{42}$ Como não havia condições da imprensa adentrar nas instalações que abrigavam o homem público, tampouco acompanhar de perto os procedimentos médicos (logicamente) o fator imagem ficou restrito ao secretário de imprensa e à divulgação das manifestações do próprio povo brasileiro por outros tipos de mídia. O que a revista fez, foi optar por aquele close de Tancredo e aí podemos pensar sobre as duas indicações de Chartier: a imagem representando o presidente enfermo ou a imagem representando o retorno da democracia em debilidade (através da "Nova República” de Tancredo). Pois, o jornalismo político na sua função de emissor de notícias e de opiniões pode ser assim interpretado:

atribui-se ao campo jornalístico uma série de comportamentos ritualísticos, característicos de uma forma privilegiada de comunicação que para as ciências humanas é considerado um processo que produz a essência do social. Esta é obtida da transformação de fatos intrigantes do âmbito da vida cotidiana em fatos do domínio do extraordinário, do que tem sentido para a vida social. Existe, dessa forma, uma proximidade entre os rituais religiosos e a prática jornalística, na medida em que criam um campo favorável à fabricação de mitos por reforçarem o carisma de pessoas e instituições. $^{43}$

Já para perceber a articulação do que ocorria no interior do hospital com o lado de fora - o resto do país, via comitiva da imprensa - temos o relato do secretário de imprensa Antonio Britto, no relato de sua experiência. ${ }^{44}$ Creio que seja de grande serventia, uma vez que ele testemunha todo o processo do internamento. Ali o

\footnotetext{
${ }^{42}$ CHARTIER. Op cit, p. 184.

${ }^{43}$ SANTOS, Anderson dos. Ligações Colloridas: o posicionamento da revista Veja em relação a Fernando Collor (1988 - 1992). Monografia de conclusão do curso de História - UFPR, 2004, p. 7. Neste trabalho - um exemplo de como encarar uma fonte imagética - o autor analisa as capas da Revista Veja durante a chamada 'Era Collor' (das eleições até o impeachmant). Isso ele faz usando o referencial da teatralização da política.

${ }^{44} \mathrm{O}$ depoimento ocorreu quatro meses após o incidente com o presidente. Foram 23h de material gravado e editado em 200 páginas. BRITTO, Antônio. Assim morreu Tancredo - Depoimento a Luís Cláudio Cunha. Porto Alegre: LP\&M, 1985.
} 
depoente expõe suas emoções e justificativas também, mas a narração é útil para entender, do outro lado, o que não podia ser mostrado na imprensa: o microcosmo do hospital que abrigava o paciente/presidente frente à nação.

Já no tom que o secretário de imprensa usa para a narrativa podemos notar conotações ao sagrado. É o caso de quando fala do ambiente tenso que se configurou no interior do Hospital. Conforme Antonio Britto, havia uma preocupação inquietante ao longo do processo em cumprir a Constituição - o 'livro sagrado' que era levado no bolso por alguns envolvidos. ${ }^{45}$ Além disso, a presença do cartaz da campanha no vidro do quarto e cujo slogan era "Muda Brasil" pede ser encarado como um ícone a abençoar o local. Aquele cartaz permaneceu ali no decurso do internamento, como um amuleto, algo que transmita segurança e proteção.

O impacto de o Salvador estar com sua vida/carreira condenada, na hipótese de frustrar as expectativas da população nacional - a quem Tancredo Neves representava por ter as mesmas aspirações em relação à democracia - fica evidente. Não só pelo número de pessoas acampadas em frente ao hospital com cartazes, rezando e torcendo pela recuperação, como igualmente no número de correspondências que o presidente eleito recebia. Da grande varanda do Instituto do Coração o porta-voz declara: "Ali fora é que se discutia e avaliava o andamento do caso, enquanto olhávamos aquele povo lá embaixo, firme, rezando, acenando para nós, nos enchendo de força" ${ }^{46}$ Sendo assim, mesmo com José Sarney já no cargo, o apoio popular era notável ao então presidente Tancredo Neves - agora enfermo. O mesmo que estava estampado nos veículos de comunicação. O mesmo a quem se dirigiam preces e cartas como as que seguem citadas:

\footnotetext{
${ }^{45}$ Britto faz questão de relatar que não se esqueceu de se munir da Constituição ao rumar às pressas para acompanhar o presidente internado às pressas. Ao longo da narrativa ele menciona: "Vamos cumprir a Constituição", “A Constituição será cumprida!”. BRITTO, Op cit, p. 34, 35.

${ }^{46}$ BRITTO, Op cit, p. 114.
} 
Estou lhe escrevendo para comunicar que eu gostaria de doar um dos meus rins para o nosso Presidente, pois só com este rim ele viverá. Sonhei bastante vezes com isso. (Motorista desempregado Luís Lima, Paranaguá, Paraná)

Me surgiu uma idéia: uma corrente humana do Rio a São Paulo, saindo do Cristo Redentor até o Instituto do Coração e rezamos com as mãos dadas. Assim o presidente ficará bom. A corrente tem que terminar aí em São Paulo, o último elo tem que ser as mãos do Presidente. Senhor assessor, não hesite em convocar o povo, pois este é o caminho. (Jorge Costa, Bonsucesso, Rio de Janeiro)

Deus veja tudo isso logo

a lágrima, o desespero e o choro

marcando o rosto do teu povo.

Salve vovô Tancredo

Sinta nossa fé, a da vovó Risoleta.

Deus, o Senhor é pró Tancredo

Disso ele, eu e todos nós temos certeza.

Somos filhos da natureza.

(Antonio Vieira, Teresópolis, Rio de Janeiro)

Note-se como a atmosfera de religiosidade característica da população brasileira perpassa o imaginário político, revelando a fé, o otimismo e a solidariedade. A representatividade do líder mostrava ultrapassar o apoio dos membros de sua "aliança” ou de outros políticos que o visitavam. Nessas correspondências enviadas ao hospital, na multidão que se concentrava ali em frente, encontramos também o apoio de pessoas simples, talvez não tão instruídas, de crianças, mostrando que o personagem era um herói respaldado, construído, querido pela sociedade em geral.

A medicina não consegue resultados satisfatórios e se confundem o otimismo dos médicos, dos jornalistas que divulgam o quadro de saúde de Tancredo Neves e a esperança da população - ou todas as alternativas. Nesse momento fica nebulosa a linha entre a vida pública de Tancredo Neves e a vida privada. Entre o homem, pai, esposo e o estadista, o Presidente da Nova República. O paciente consegue sobreviver à Semana Santa: não faleceu na sexta-feira da 
paixão, mas não recebeu alta no domingo de ressurreição. “Tanto a idéia de recuperação, que levava à salvação, quanto à idéia do agravamento, que levaria à morte, identificava o Dr. Tancredo com o martírio de Cristo" ${ }^{47}$, observa o secretário de imprensa.

Não foi na sexta-feira da paixão, mas no dia de Tiradentes que o presidente veio a falecer! Com setenta e cinco anos, após oito cirurgias, em 21 de abril de 1985.

$$
* * *
$$

“Adeus”. Era o único texto que enunciava a manchete da revista "Veja" em 01 de maio de 1985. A despedida nesse texto em cor de luto está sublinhada, no rodapé da fotografia de pano de fundo. Ela retrata o caixão, de longe e de costas, sendo levado ao Palácio do Planalto. Uma despedida, em que aparecem vestígios da bandeira verde-amarela cobrindo o presidente. Portanto a última edição que traz nosso protagonista como assunto, não estampa sua face como outrora (em close e cabisbaixo) e o caixão quase não se enxerga. Estaria ele somente voltando ao local onde deveria estar? Era assim que deveria ficar lembrado? É o que leva a entender...

Se a prática jornalística encerra uma função crucial como ferramenta para a constituição do mito, isto não se restringe à comoção que o evento desencadeou para o povo/expectador devido à função divulgadora. Através da espetacularização da morte do presidente que não chegou a assumir, a mídia ainda ganha o papel de colaboradora para transpor o mito do Salvador em Mártir - e as tonalidades sagradas que estão sendo detectadas no terreno político continuam presentes.

Frente à morte, o homem não pode exercer o poder, mas transportando esse poder ao corpo martirizado, a referência de poder, líder, e Salvador continua e se perpetua. ${ }^{48}$ Seria uma personificação

${ }^{47}$ Idem, p. 138.

${ }^{48}$ BREPOHL. Op. cit. 
daquilo que o homem representava (a democracia, no caso de Tancredo), estendida e perpetuada à semelhança do que ocorreu com Cristo (lembrado na cruz, morrendo pelos pecados da humanidade).

Um exemplo dessa questão é o estudo de Rafael Rosa Hagemeyer ${ }^{49}$ sobre o estudante Edson Luís, morto pela polícia durante um confronto entre o movimento estudantil e as tropas do governo, em 1968. Ano em que o movimento estudantil tomava grandes proporções como forma de protesto àquela época. Ora, conforme Hagemeyer, Edson era um estudante comum, que trabalhava no Restaurante Calabouço (de onde ocorreu a manifestação) e nem tinha um engajamento significativo no movimento. Sua morte virou emblema da luta, visto como um santo nacional através da imagem linda que foi divulgada. Foi usado como 'arma' e 'escudo' pela multidão durante o confronto - quando seu corpo ainda era carregado pelos manifestantes no protesto.

Tanto Edson Luís como Tancredo Neves, mesmo com suas diferenciações para com a espontaneidade ou fabricação do herói (pensando no contexto social e na trajetória pública e privada dos dois), podem ser vistos como mártires. Como em ambos os casos o corpo físico é sacrificado deixando de ser referência, a questão do corpo martirizado se levanta como fundamental para entender esse processo de heroificação que está proposto aqui.

Sendo assim:

Sem dúvida é o cristianismo que coloca o martírio como objeto de adoração. Cristo teria morrido para redimir a humanidade de todos os seus pecados - passados e futuros. O mártir aponta o caminho da salvação ao renunciar a vida terrena, tamanha é sua fé na eternidade da alma e na verdade divina. ${ }^{50}$

Não foi uma morte simples ou banal, pois, para ser considerado um mártir deve-se ter uma morte comovente, alarmante

\footnotetext{
${ }^{49}$ HAGEMEYER, Rafael Rosa. Movimento Estudantil de 68: Imagens da Paixão. Dissertação apresentada ao curso de pós-graduação em História - UFPR, 1998.

${ }^{50}$ Idem.
} 
ou até mesmo trágica. Nos dois casos acima os atores sociais entram em uma última característica coerente com a análise de Girardet. Ela compreende os "períodos de heroificação" que o historiador francês levantou: tempo da espera e do apelo, tempo da presença e tempo da lembrança. Tancredo e Edson Luís se encontram no período do tempo da lembrança, ou seja, a figura do líder incutida na memória coletiva, seja da República brasileira ou do movimento estudantil.

Já observou Skidmore que

"Em vida, Tancredo assomava como um salvador político. Morto, assumia as proporções de um santo. Todas as esperanças acumuladas e centralizadas no homem que não viveu para materializá-las, manifestaramse impetuosamente". ${ }^{1}$

A fragilidade tanto de sua doença como da própria transição para o regime aberto se confundiam, e sua morte, à 21 de abril de 1985 - dia de Tiradentes, o herói nacional - veio mostrar a efervescência dos sentimentos e da razão (características próprias do ser-humano) em uma fronteira muito nebulosa entre essas características, se é que ela existe.

$$
* * *
$$

No caso do presidente que não tomou posse, sua morte interrompeu uma significável jornada política já construída. A larga experiência enquanto estadista a postura de "pai", "tutor" e "moderador" que pretendi iluminar, demonstram o caráter de líder carismático na figura daquele senhor que traria a "Nova República”.

A eminente conquista do líder e da nação (porque as aspirações acerca da democracia eram as mesmas e um encontrava-se no outro, conforme já vimos) é interrompida, causando um grande choque do calvário até a cruz em meio àquele processo de transição. Não só a posse fora prejudicada. O próprio exercício do cargo é impedido, deixando ao vice-presidente José Sarney todas as

${ }^{51}$ SKIDMORE. Op cit. p. 500. 
competências antes confiadas ao "candidato da conciliação", o herói da República naquele momento.

A morte de Tancredo aproxima-o ainda mais dos atributos sagrados emprestados do referencial mais forte de religiosidade no ocidente - o cristianismo. Isto é, além de um mito político pela trajetória de sua vida e pelo processo histórico-político brasileiro, o evento de sua morte acaba por martirizá-lo, aproximando-o ainda mais do Salvador. E a maneira pela qual a mídia expôs a situação, particularmente a revista "Veja", mostrou-se ferramenta indispensável na construção desse mito.

Isto acentua umas das principais características da República brasileira, que tem nas figuras, nas imagens representativas de seus líderes, poder tão intenso, ou maior que o próprio discurso ou conteúdo ideológico de promoção. Mostra ainda que "as ações do homem no tempo" podem ser compreendidas na interação do subjetivo com o objetivo e nas imbricações entre razão e emoção, manifestando uma dupla função: reestruturação psíquica e reinserção social, renovando significados que podem caracterizar uma época, um conceito, ou até mesmo a morte.

\section{BIBLIOGRAFIA}

ANSART, Pierre. Ideologias, Conflitos e Poder. Rio de Janeiro: Zahar, 1983.

ARENDT, Hannah. Entre o passado e o futuro. Ed. Perspectiva, cap 3.

BREPOHL, Marion. Leituras da História: La gestion dês passions politiques - Pierre Ansart. Texto apresentado no III Evento de Extensão em Pesquisa Histórica - Fontes Históricas: Métodos e Tipologias, 2008.

BRESSER-PEREIRA, Luis Carlos. Economia Brasileira. São Paulo: Ed. 34, 1998, cap. 27. 
BRITTO, Antônio. Assim morreu Tancredo - Depoimento a Luís Cláudio Cunha. Porto Alegre: LP\&M, 1985.

CHARTIER, Roger. O Mundo como representação. Texto publicado com permissão da revista Annales nov/dez 1989, No 6, p. 1505-1520 em Estudos Avançados, 1991, No 5, p. 173-191.

DICIONÁRIO Histórico-Biográfico Brasileiro.

GIRARDET, Raoul. Mitos e mitologias políticas. São Paulo: CIA das Letras, 1987.

HAGEMEYER, Rafael Rosa. Movimento Estudantil de 68: Imagens da Paixão. Tese apresentada ao curso de pós-graduação em História UFPR, 1998.

OLIVEIRA, Eliézer Rizzo de. De Geisel a Collor: Forças armadas, transição e democracia. Campinas: Papirus, 1994.

PATLAGEAN, Evelyne. A História do Imaginário. In: LE GOFF, Jacques (org) A História Nova. São Paulo: Martins Fontes, 1990, p. 292-316.

REIS, José Carlos. Escola dos Annales - A inovação em História. São Paulo: Paz e Terra, 2000.

SANTOS, Anderson dos. Ligações Colloridas: o posicionamento da revista Veja em relação a Fernando Collor (1988 - 1992). Monografia de conclusão do curso de História - UFPR, 2004.

SKIDMORE, Thomas. Brasil: de Castelo à Tancredo. Rio de Janeiro: Paz e Terra, 1988.

\section{Revistas Consultadas (capas):}

VEJA. Noite em Brasília: o choque e a posse. São Paulo: Editora Abril, 20 de março, 1985, n 863.

VEJA. Tancredo: A luta pela vida. São Paulo: Editora Abril, 27 de março, 1985. $\mathrm{n}^{\circ} 864$.

VEJA. Tancredo: uma semana entre a vida e a morte. São Paulo: Editora Abril, 03 de abril, 1985. $n^{\circ} 865$. 
VEJA. Dias de dor: a resistência da infecção; o perigo nos pulmões; o choque das operações sucessivas, São Paulo: Editora Abril, 10 de abril, 1985, $\mathrm{n}^{\circ} 866$.

VEJA. Tancredo: a cruel agonia. São Paulo: Editora Abril, 17 de abril, $1985 . n^{\circ} 867$.

VEJA. Tancredo: por que os médicos mentiram. São Paulo: Editora Abril, 24 de abril, $1985 . n^{\circ} 868$.

VEJA. Adeus. São Paulo: Editora Abril, 01 de maio, 1985. nº 869.

\section{Site Consultado:}

http://www.veja.abril.com 